\title{
Maxims in Movie Script Percy Jackson: Sea Of Monsters
}

\author{
Ni Luh Yunita Putri \\ English Department, Faculty of Arts, Udayana University \\ [Yunita.caputri@gmail.com]
}

\begin{abstract}
This study is entitled Analysis of Maxims in Movie Script Percy Jackson: Sea of Monsters. The aims of this study are to identify the maxims applied in the movie Percy Jackson: Sea of Monsters and to identify the maxims flouted in the movie Percy Jackson: Sea of Monsters. The data of this study were obtained from the internet in the form of movie and movie script entitled Percy Jackson: Sea of Monsters. The method of collecting data was documentation method; the method was done by watching and note taking techniques. The qualitative method was used to analyze the data and the method was done by the descriptive technique. The method of presenting analysis was narrative method and was done by argumentative technique. This study found that all the types of maxims were flouted but not all the types of maxims were applied. The character of this movie mostly flouted the maxim rather than applied the maxim. The maxim that mostly flouted was the maxim of manner and the maxim that mostly applied was the maxim of quality. It can be concluded that although the characters did not apply maxim, the conversation would still be going.
\end{abstract}

Keywords: Maxim, maxim application, flouting maxim

\begin{abstract}
Abstrak
Penenelitian ini berjudul Analysis of Maxims in Movie Script Percy Jackson: Sea of Monsters. Tujuan dari penelitian ini adalah untuk mengidentifikasi maxim yang diaplikasikan di dalam film Percy Jackson: Sea of Monsters dan mengidentifikasi maxim yang dilanggar di dalam film Percy Jackson: Sea of Monsters. Data dari penelitian ini diperoleh dari internet dalam bentuk film dan naskah film yang berjudul Percy Jackson: Sea of Monsters. Metode yang digunakan untuk mengumpulkan data adalah metode dokumentasi, metode tersebut dilakukan menggunakan teknik menonton dan mencatat. Metode kualitatif digunakan untuk menganalisis data-data dan metode tersebut dilakukan dengan menggunakan teknik deskriptif. Metode untuk mempresentasikan analisis adalah naratif dan dilakukan dengan menggunakan teknik argumantatif. Temuan dalam penelitian ini adalah semua tipe dari maxims dilanggar tetapi tidak semua tipe dari maxims diaplikasikan. Karakter dari film ini sebagian besar melanggar maxim dibandingkan mengaplikasikan maxim. Maxim yang paling sering dilanggar adalah maxim of manner dan maxim yang paling sering diaplikasikan adalah maxim of quality. Dapat disimpulkan bahwa walaupun seseorang tidak mengaplikasikan maxim, percakapan akan tetap berjalan.
\end{abstract}

Kata kunci: maxim, pengaplikasian maxim, pelanggaran maxim

\section{Background of the Study}

Pragmatics is concerned with the study of meaning as communicated by a speaker and interpreted by a listener.
This has more to do with the analysis of people's utterance meaning than what the words or phrases in those utterances might mean by themselves. According to Yule (1996: 3), pragmatics is the study of 
speaker's meaning. When the speakers deliver their utterances, the listeners are expected to understand what the actual meaning of the speaker. One of the aims of pragmatic study is to know how competent language users are able to derive the form of linguistics which is an utterance and the context of situation. It is related to how conversation can be as effective as needed.

Grice (1975: 26) stated that our talk exchanges do not normally consist of a succession of disconnected remarks. In a conversation, the participants are expected to obey principal rules to obtain informative communication. The rules proposed by Grice are called Maxims. There are four types of Maxims or rules of talk such as: Maxim of Quantity, Maxim of Quality, Maxim of Relation, and Maxim of Manner. The rules of talk or maxim are expected to make the speakers talk adequately, truthfully, relevantly, and orderly.

Theoretically, people should apply the four types of maxims in communication to reach an effective communication. However, some people may sometimes intentionally flout those four types of maxim. Black (2006: 25) explains that a speaker who flouts maxims is actually aware of the Cooperative Principles Maxims. In other words, it is not only the maxims that are flouted but the speaker also chooses an indirect way to achieve the cooperation of the communication. Grice (1975: 30) stated that the speaker blatantly and deliberately fails to fulfil a certain maxim because the speaker wants to express any implicit meaning hidden behind the literal meaning.

It is very interesting to investigate the four types of maxims applied and flouted in movie Percy Jackson: Sea of monsters to prove that although people do not apply or use the rules of maxim, the conversation would still be going.

\section{Problems of the Study}

a) What maxims are applied in the movie Percy Jackson: Sea of Monsters?

b) Why are the maxims flouted in the movie Percy Jackson: Sea of Monsters?

\section{Aims of the Study}

a) To identify the maxims applied in the movie Percy Jackson: Sea of Monsters.

b) To identify the maxims flouted in the movie Percy Jackson: Sea of Monsters.

\section{Research Method}

There are four aspects of research methods applied, which are data source, method and technique of collecting data, method and technique of analyzing data, and method and technique of presenting analysis.

\subsection{Data source}

The data were in the form of movie script taken from a movie entitled Percy Jackson: Sea of Monsters. The genre of the movie is fantasy adventure. It is movie adaption from a novel entitled Percy Jackson: The Sea of Monsters by Riordan that was published on April 1, 2006. The movie was released on August 7, 2013 and directed by Thor Freudenthal. It is the second series of Percy Jackson \& the Olympians: The Lightning Thief. The main character of this movie is Percy Jackson who is in charge of finding Golden Fleece at the Sea of Monsters in order to heal Thalia's tree.

This movie was chosen to be the data source of this study because this movie is quite new and famous that ables to attract the interest of the audience for seven years already. Another reason is 
the fact that are many flouting maxims found in this movie.

\subsection{Method and technique of collecting data}

The method of collecting data was documentation method. The movie were obtained by downloading from the internet. It was accessed on July 19, 2016, 11.20 from http://ganool.se/film/percy-jackson-seaof-monsters-2013-bluray-720p-750mbganool-is. The movie script was taken from

https://www.springfieldspringfield.co.uk/ movie script.php?movie=percy-jacksonsea-of-monsters and accessed on September 18, 2017, 18.30. The method was done by using the watching and note taking techniques in order to identify Grice's Maxim applied and flouted in the movie Percy Jackson: Sea of Monsters. The movie was watched carefully in order to find the maxim applied or flouted by the character. Then, the utterances that were considered applying or flouting maxims were selected by using the note-taking technique. While doing note-taking, it is also important to check the sentence in the movie script.

The data were chosen for its purposive sampling in the classification of maxims. In this movie script, there were only 7 classifications of maxim found. Therefore, from 75 maxims in total found in this movie script, 21 data were analyzed based on the classification. Each classification was analyzed by 3 data.

\subsection{Method and Technique of Analyzing Data.}

Qualitative method was used to analyze the data. The method was done using the descriptive technique. In order to analyze the data, the conversations were investigated based on the Theory of
Maxims and Flouting Maxims proposed by Paul Grice (1975).

The data were analyzed in terms of some steps. First, the collected data were classified based on the maxims applied and flouted found in the movie Percy Jackson: Sea of Monsters. The classified data were chosen randomly as the best representative data for each type of maxim and flouting maxim involved. Then, all the representative data were collected and the selected data were further analyzed based on Maxims and Flouting Maxims theory by Paul Grice (1975).

\subsection{Method and Technique of Presenting Data}

This study used narrative method and argumentative technique in presenting the data. Narrative method means that the data were presented narratively based on the theory by describing and explaining them in sentences. The description of each maxim applied and flouted was presented in the form of paragraph. Meanwhile, argumentative technique means the data were analyzed argumentatively based on the theory by giving opinion or argument about what maxim was applied or flouted by the characters.

\section{Result and discussion 5.1 Maxim Application}

The following three analysis present which maxim were applied by the characters in the movie.

\subsubsection{Maxim of Quantity}

Luke : Grover, are you okay?

Grover : My leg. It's stuck.

Luke : Come on. I got you.

The dialogue above shows that Grover applies maxim of quantity because he gives information as 
informative as is required. When Luke, Annabeth, Thalia and Grover were kids. They were chased by 2 Cyclops that wanted to kill them. The Camp HalfBlood is the only safe place for their kids which is half-bloods. Half-blood is a child from the marriage of God and human. There are 12 gods based on the Greek mythology. Each god has their own power and inherit it to their children. Luke is the heir of Hermes / God of Thieves and Commerce, Annabeth is the heir of Athena / God of Wisdom, Thalia is the heir of Zeus / God of the Sky and Grover is a satyr / half goat and half human.

When they were headed to the Camp, Grover stroked down by tree branch. It made their friends panic, Luke asked his condition by saying Grover, are you okay? Grover then answered by saying My leg. It's stuck. Grover's statement shows that he applies maxim of quantity because he gives information as informative as required whereas Grover does not give any other information. By saying My leg. It's stuck, Grover makes Luke understand enough about his condition that Grover is not okay.

\subsubsection{Maxim of Quality}

Tyson : But we don't know where he is.

Annabeth : I know someone who does. Come on.

Percy : What, are we shipping ourselves overnight express to the Sea of Monsters?

Annabeth : You want to find Luke? His dad will know he is.

On the dialogue above, Annabeth applies maxim of quality because she gives truth information. Percy, Tyson, Annabeth and Grover live in the Camp Half-bloods where only half-bloods can live there. Half-blood is a child from the marriage of god and human based on the
Greek mythology. Percy is the heir of Poseidon / god of the Sea, Annabeth is the heir of Athena / god of Wisdom, Tyson is the child of Poseidon and Sea Nymph, Grover is a satyr / half goat and half human. The reason why they live in the camp is that it is the only safe place for their kinds. The camp has barrier which is Thalia's tree, it can protect them from the monsters that want to kill them. Unfortunately, Luke has poisoned the tree, it makes the barrier disappear. Luke also lets the bull come into the camp to destroy the camp; he wants to destroy the Olympus as well. He thinks that his father Hermes and other gods do not care about him and other half-bloods. He has plan to revive the evil Kronos by covering Kronos's coffin with Golden Fleece because Luke believes that Kronos can destroy the Olympus. Someone that can help him to get the Golden Fleece is Grover, because of that he kidnaps him.

Annabeth, Percy and Tyson want to get Grover back, but they don't know where Luke is. But suddenly Annabeth says I know someone who does. Come on, she applies maxim of quality because she gives true information or based on the fact information. It is proven by saying You want to find Luke? His dad will know he is. She then brings them to the store which the owner of the store is Hermes. It means Luke's father absolutely will know where he is.

\subsubsection{Maxim of Manner}

Percy : What do you have against Tyson anyway?

Annabeth : He's a Cyclops.

Based on the dialogue above, Annabeth applies maxim of manner because she gives clear information. Percy and Annabeth are half-bloods. Half-blood is a child of god and human based on the Greek mythology. Percy is 
the heir of Poseidon / god of the Sea meanwhile Athena is the heir of Athena / god of Wisdom. All the half-bloods have to live at Camp Half-bloods because it is the only safe place for their kids. The camp has barrier which is a tree, it protects them from the monsters that want to kill them. The tree is the transformation of Thalia who is the daughter of Zeus. She died when she was young when trying to save Annabeth, Luke and Grover from the two Cyclops that want to kill them. Unfortunately, the barrier disappears because Luke has poisoned the tree. He wants to destroy the Olympus because he thinks that his father Hermes and other gods do not care about him and other campers.

Luke has a plan to revive the evil Kronos, so Kronos can destroy the Olympus as he wants. It needs Golden Fleece to revive Kronos, so he influences the other campers to help him get the Fleece. Not only Luke that needs the Fleece, Percy, Annabeth, Tyson and Grover also needs it because it can heal the tree. They have to go through the Sea of Monsters and steal it from the Cyclop Polyphemus. Luke needs Grover to help him get the Fleece, so he kidnaps Grover. When Percy, Annabeth and Tyson want to get Grover back, Luke puts them in the brig. Then, Annabeth blames Tyson, she thinks that Tyson always makes problems. Then, Percy asks Annabeth by saying What do you have against Tyson anyway? Annabeth answers by saying He's a Cyclops. She applies maxim of manner because she gives clear information. All of the campers know that her best friend Thalia was killed by a Cyclop, because of that Annabeth really hates Cyclop. On the other hand, Tyson who is a Cyclop suddenly comes into the camp and says that he is the heir of Poseidon too; he is not a child of human, but Sea Nymph. It makes Annabeth hates him more. By saying He's a Cylops, it shows that she gives Percy brief explanation why she hates Tyson.

\subsection{Flouting Maxim}

The following four analysis presents which maxim are flouted by the characters in the movie.

\subsubsection{Flouting Maxim of Quantity}

\section{Annabeth : It feels like she's dying all over again. Who would do this? \\ Percy : Luke poisoned the tree}

Based on the dialogue above, Percy flouts maxim of quantity because he gives the information more than is required. Percy is a half-blood who lives at the Camp Half-Blood. Half-blood is a child from the marriage of god and human based on the Greek mythology. Half-bloods have to live in the camp in order to avoid the monsters that want to kill them. The camp has barrier which is a tree that has magical powers. The tree is a transformation of Thalia, daughter of Zeus who sacrificed her life to save her friends from the Cyclops.

Half-bloods that live in the camp are usually called campers or demigod. The campers are panic because the barrier suddenly disappears and a large mechanical bull is able to come into the camp. The bull attacks and destroys the camp. Fortunately, Percy succeeds defeating the bull. However, Luke suddenly appears out of nowhere and he says to Percy that he has poisoned the tree that is why the bull is able to come into the camp. When the other campers check the tree, they find out the tree is poisoned, but they do not know who the suspect is. Then Annabeth asks by saying It feels like she's dying all over again. Who would do this? Percy answers by saying Luke poisoned the tree. Percy's statement proves that he flouts maxim of quantity because he gives information 
more than is required. The statement poisoned the tree is not necessary to be said. Percy is supposed to say Luke because the campers already know that the tree is poisoned, so there is no need to add statement poisoned the tree. The reason why Percy flouts maxim of quantity is he just wants to emphasize the statement poisoned the tree. He wants to make sure that the campers will know that Luke is the suspect.

\subsubsection{Flouting Maxim of Quality}

Percy : Is there any chance, any chance at all that I might not be the guy in the prophecy?

Chiron :The Oracle references a halfblood of the eldest gods. You are the only living half-blood heir of Zeus, Hades or Poseidon. The prophecy could refer only to you.

Chiron flouts maxim of quality because he gives information that is lack of adequate evidence. Chiron is the activities director of Camp Half-Blood. Half-blood is a child from the marriage of god and human based on the Greek mythology. Percy is the heir of Poseidon / god of the Sea. There are 12 gods, each god has their own power and inherit their power to their child. Half-bloods must live in the Camp Half-Blood because it is the only safe place for their kinds. The camp has barrier that protects them from the monsters that want to kill them. Their barrier is a tree which is a transformation of Talia, daughter of Zeus that sacrificed her life to save their friends from the Cyclops. Unfortunately, Luke has poisoned the tree because he wants to destroy Olympus. All of the campers are panic because their barrier disappears and that means monsters can come into their camp to kill them. Luke wants to revive the evil Kronos in order to revive him, Luke has to steal Golden Fleece from Polyphemus. However, if Luke is successful to revive Kronos, Kronos will destroy the Olympus. Not only Luke, the campers also need the Fleece to heal the tree.

Luke lets the bull come in and destroy the camp. When Percy succeeds in defeating the bull, Luke appears out of nowhere and tries to make Percy turn into his side and destroy the Olympus. Luke also says about prophecy that is related to Percy. The prophecy says that only the child of the three eldest god can defeat the evil Kronos whereas he is fated to rise again after being banished by his children to the depth of Tartarus. The prophecy also says that the child of the eldest god can save or destroy the Olympus. Percy then asks Chiron about the prophecy by saying Is there any chance, any chance at all that I might not be the guy in the prophecy? Chiron answers by saying The Oracle references a half-blood of the eldest gods. You are the only living half-blood heir of Zeus, Hades or Poseidon. The prophecy could refer only to you. The sentence The prophecy could refer only to you shows that Chiron flouts maxim of quality because he does not give true information and he does not give Percy the evidence that he is the only heir of Zeus, Hades or Poseidon. The word could shows that Chiron does not give Percy certainty about the prophecy. In fact, there is another half-blood that the heir of the eldest God Zeus, Hades and Poseidon. The Golden Fleece does not only heal the tree, but Thalia as well. Thalia is the heir of Zeus that means the prophecy can also refer to Thalia. Chiron flouts the maxim of quality because Chiron wants Percy to believe about his prophecy that says he can save or destroy the Olympus. 


\subsubsection{Flouting Maxim of Relation}

Grover : I'm sure you don't get summoned to the Big House without a major-league screwup.

\section{Percy : I didn't screw up. I cleaned the entire coliseum and vacuumed.}

The dialogue above shows that Percy flouts the maxim of relation because he gives irrelevant information. Three of them are half-bloods that live in Camp Half-Blood to avoid getting killed by the monsters. The camp is surrounded by the barrier of Thalia's tree, it makes the monsters unable get into the camp. Half-Blood is the child from the marriage of god and human. Percy is the heir of Poseidon, Annabeth is the heir of Athena, and Grover is a satyr / half goat and half human. There is a dexterity competition in the Camp Half-Blood, but not all the campers join the competition. Clarisse won the competition instead of Percy. She then mocks him because he cannot win over her. Then, Mr. D tells Percy to clean the entire coliseum and vacuumed.

Percy tells Grover and Annabeth that he is summoned by Mr. D. If the campers get summoned by Mr. D or Chiron, it means that they made a problem and had to get a punishment. Grover then answers I'm sure you don't get summoned to the Big House without a major-league screw-up. Grover is sure that Percy made a problem so he gets summoned. However, Percy responds by saying I didn't screw up. I cleaned the entire coliseum and vacuumed. Percy flouts the maxim of relation because he gives the answers that are not relevant with his previous answer. He should just say that he didn't screw up than add another information by saying I cleaned the entire coliseum and vacuumed. $\mathrm{He}$ is not expected to tell about his previous activity. The reason why he flouts the maxim is that he thinks that if he says that he cleans and vacuums the entire coliseum, it will make Grover and Annabeth believe him that he is doing something great rather than making problems.

\subsubsection{Flouting Maxim of Manner}

Grover : Holy Styx. Another Poseidon half-blood.

Chiron : Not exactly. Technically, Tyson is not a half-blood. Half -bloods are halfhuman, hence the name.

Based on the dialogue above, Chiron flouts the maxim of manner by giving ambiguous statement. Every halfblood knows that Percy is the only heir of Poseidon. Half-blood is a child from the marriage of god and human. All of the half-blood live in the Camp Half-Blood which is the only safe place for them whereas the camp has barrier. It protects them from the monsters that want to kill them. Only half-bloods that can come into the camp. Suddenly someone is successful to come into the Camp although he is not a half-blood. It makes Chiron and Mr.D which is the director of the camp confused about this case whereas it never happens before. The weirdest thing is that he does not look normal which is he only has 1 eye. He explains that he is the heir of Poseidon.

Chiron tells Percy and his friends Grover and Annabeth that his belief that Percy is the only heir of Poseidon maybe not true. Grover then concludes that Percy has a brother but Chiron says Not exactly. Technically, Tyson is not a halfblood. Half -bloods are half-human, hence the name which is not clear information or ambiguous. It is also proven by the next statement that is said by Percy I don't get it. If this new kid is 
not half-human, then what other half is he? It means that Chiron's statement is categorized as flouting the maxim of manner whereas it is not clear enough to make the listener understand. He should just say that Tyson is Percy's brother or not instead of explaining that Tyson is not a half-blood. The reason why Chiron flouts the maxim of manner is that Chiron prefers to tell Percy about Tyson slowly instead of directly saying that Tyson is a child of Sea Nymph in order to not make Percy shock whereas he believes that he is the only Poseidon's heir.

\section{Conclusion}

From the analysis of the data it can be concluded that the characters mostly flout the maxims rather than apply the maxims. All the types of maxims were flouted, but not all the types of maxims were applied. Speakers tend to flout maxim than apply it because sometimes they want to emphasize the point of their utterances.

Out of all the data, there were the representative data that analyzed based of the types of applying and flouting maxim. First, flouting the maxim of manner, there were three findings out of 24 data. Second, flouting the maxim of relation, there were three findings out of 11 data. Third, flouting the maxim of quantity, there were three findings out of 11 data. The last one is flouting the maxim of quality; there were three findings out of 7 data. On the other hand, there were three findings out of 14 data applying maxim of quality. There were three findings out of 4 data applying maxim of quantity. There were three findings out of 4 data applying maxim of manner. However, there is no data found applying maxim of relation.

Basically, in order to make effective communication, both the speaker and hearer should apply Cooperative Principles or Maxims. However, the analyzed data proves that although the speaker or hearer mostly flouts the Cooperative Principles or Maxim, they still get the cooperation of communication. The speaker or hearer sometimes intentionally flouts maxim in order to express the implicit meaning hidden behind the literal meaning.

\section{Refrences}

Black, E., (2006). Pragmatic Stylistics. Edinburgh:Edinburgh University Press.

Evitayanti, Ni Wayan., (2016). Flouting Maxims in the Movie "How to Train Your Dragon 2" (thesis). Denpasar: Udayana University.

Grice, Herbert Paul., (1975). Logic and Conversation. New York: Academic Press.

Hidayati, Lut Husaini Widi., (2015). A Pragmatic Analysis of Maxim Flouting Done by the Main Characters in the Devil Wears Prada (thesis). Yogyakarta: Universitas Negeri Yogyakarta.

Holmes, Janet., (1995). Women, Men and Politeness. London: Longman.

Inayati, Citraresmana and Mahdi., (2014). Flouting Maxims in Particularized Conversational Implicature. No.6, July, pp5361.

Levinson, Stephen., C. (1983). Pragmatics. Cambridge: University Press.

Percy Jackson: Sea of Monsters. Available from: https://en.m.wikipedia.org/wiki/ Percy Jackson: Sea of Monst 
$\underline{\text { ers }}$ [Accessed on May 12, 2017, 13.00.]

Percy Jackson: Sea of Monsters. Available from: http://ganool.se/film/percyjackson-sea-of-monsters-2013bluray-720p-750mb-ganool-is [Accessed on July 19, 2016, 11.20.]

Percy Jackson: Sea of Monsters Movie Script. Available from: https://www.springfieldspringfi eld.co.uk/movie script.php?mo vie=percy-jackson-sea-of-

monsters [Accessed on September 18, 2017, 18.30.]

Putri, D.N.A.P., (2011). Grice's Maxims in Interview between Oprah Winfrey and The Casts of Eclipse Movie (thesis). Denpasar: Universitas Udayana.

Yule, G., (1996). Pragmatics. Oxford: Oxford University Press. 